\title{
Studying Liquidity Premium Pricing, Size, Value and Risk of Market in Tehran Stock Exchange
}

\author{
Hassan Ghalibaf Asl ${ }^{1}$, Mehdi Karimi ${ }^{2}$ \& Elham Eghbali ${ }^{3}$ \\ ${ }^{1}$ Faculty of Social Sciences \& Economics, Alzahra University, Tehran, Iran \\ ${ }^{2}$ Faculty of Economic Institutions Management, University of Economic Sciences, Tehran, Iran \\ ${ }^{3}$ School of Management \& Economics, Islamic Azad University, Science \& Research Branch, Tehran, Iran \\ Correspondence: Mehdi Karimi, School of Institutes Management, University of Economic Sciences, Tehran, \\ Iran. Tel: 98-212-2995-4205. E-mail: mahdikarimi_1386@yahoo.com
}

\author{
Received: May 8, $2012 \quad$ Accepted: July 16, $2012 \quad$ Online Published: July 31, 2012 \\ doi:10.5539/ijef.v4n9p164 URL: http://dx.doi.org/10.5539/ijef.v4n9p164
}

\begin{abstract}
Capital asset pricing model (CAPM) considers systematic risk as the only risk priced by the market. In addition to systematic risk, Fama and French three-factor model indicates that the risk of firm size and book to market equity are also priced by the market. In addition to three risk factors addressed by Fama and French, liquidity risk and its pricing by investors in Tehran Stock Exchange is studied by a multivariable regression between 2004 through 2008. Research findings indicate that stock return in Tehran Stock Exchange can be clarified by four factors including market excess return, firm size, BE/ME ratio and stock transaction turnover in a relative plausible level (\%40 in average). In the meantime, a significant relationship is observed between market excess share, firm share and stock return. No significant relationship is seen between BE/ME ratio and stock transaction turnover and stock return. In other word, only market risk and firm size (ME) are priced by market.
\end{abstract}

Keywords: liquidity premium, stock transaction turnover, value premium, size premium

\section{Introduction and Problem Description}

Investors' expected ROI is one of the most important determinants of stock price. A popular provided model in this regard is capital asset pricing model (CAPM). In this model, only market risk is considered while in Fama and French model, firm size and book value to market share value are considered in addition to market excess return. Liu (2006) believes that CAPM and Fama and French model cannot explain liquidity premiums on stock returns. Although CAPM and Fama and French three-factor model highly impact on determining stock return, some evidences show that there is another factor called liquidity as an affecting factor on stock return. So, the problem is that CAPM and Fama and French three-factor model cannot determine stock return alone. Therefore, by studying raised variables in financial researches and by using Fama and French three-factor model, we address to the power of determining stock return of accepted firms in Tehran Stock Exchange by such factors as market excess return, firm size, book to market equity and liquidity. It is expected that studied variables especially stock liquidity enjoy more power in determining stock return.

\section{Reviewing Research Background}

Risk and return are always considered simultaneously for decision-making. In fact, risk and return are two main pillars of decision-making for investors. Treynor, Sharp and Linter proposed CAPM to achieve balanced prices for securities. The results of experimental tests on CAPM show that systematic risk is not alone able to describe and determine stock return. Since 1970s, various tests by Block, Jensen and Schulz (1972), Fama and Macbeth (1973), Blum and Friend (1975) and Francis (1983) indicate that CAPM is not able to clarify and determine expected return. In 1993, Fama and French studied three factors including market risk (Beta), size and book value to market share value to determine stock return which became famous as Fama and French three factor model. Tang and Sham studied the relationship between risk factors and returns in Asian emerging markets. They tested Fama and French three-factor model in Asian emerging markets (Hong Kong, Singapore and Taiwan). Empirical evidences are similar to the results of US firms study which enounces the greatest average of returns. The most important factor in determining return in this research is market excess return. The impact of size and book to market equity is limited and is meaningless in some cases (Tang et al., 2005). Marshal and 
Young (2003) studied the relationship between liquidity and stock return. Used liquidity measures in this research are the gap between sales and buy suggested prices and turnover rate. They used market return and size firm factors. The results of their researches show that the impact of firm size on stock return is negative. Chan and faff (2003) studied the impact of assets liquidity in Australian market by using stock turnover rate in asset pricing. They used monthly data and controlling factors like book value to market value, firm size and market excess return. Chen (2005) studied risk premium of asset pricing in US market. Initially, it explained liquidity premium with macro economic variables with a long term attitude. Then, the impact of such factors on pricing are considered. In the meantime, constructed profiles in Fama and French three-factor model are compared to controlling variables such as firm size and book to market equity (Khoramdin, 2007). Chui and Wei (1998) found that the impacts of size and liquidity play more effective role in stock return. Amihud \& Mendelson (1996) investigated the impact of distance between sales and buy suggested prices of assets on their prices and developed a model which showed that assets with more gap achieves more expected return and the impact of customer causes that investors to select higher gaps to attain higher return. Datar et al, (1998) provided a different test of Amihud \& Mendelson to show the impact of liquidity on stock return and they used turnover ratio (the number of transacted stocks to the number of issued stocks) as liquidity alternative variable. Overall, they show that stocks with low turnover achieve higher return than stocks with higher turnover. Rouwenhorst (1999) based his study on the relationship between expected return and stock transaction turnover and studied turnover trait as a return internal factor. He concluded that there is no evidence on the relationship between expected returns and stock turnover. However, Beta $(\beta)$, size, velocity, B/M value and $\mathrm{E} / \mathrm{P}$ value have a positive periodical positive relation to stock turnover in emerging markets. He points that in is unlikely that liquidity can explain return premiums of emerging markets. Lee et al, (2000) studied the relationship between the volume of transactions and periodical returns. They used stock daily turnover to define the volume of transactions where stock daily turnover is the ratio of transacted stock quantity of one day to issued stocks at the end of the same day. Lee et al, (2000) concluded that firms with low (high) stock turnover achieve low (high) future returns. Easley et al, (2002) used the proportionate of stock turnover to test Amihud and Mendelson (1986) model empirically. They reported convincing evidences on securities where expected return and stock turnover have a reversed relationship and investors demand a premium to maintain stocks with low liquidity.

In his paper, Liu (2006) addressed to the role of liquidity risk on assets periodical return. His findings indicate that two-factor model (market and liquidity) perform better than CAPM and Fama and French three-factor model in explaining the periodical return. Datar et al, (1998) recommended Amihud and Mendelson turnover ratio in 1986 as an index for liquidity. They found that liquidity plays a significant role in explaining stock return. They used such controlling factors as firm size, book to market equity ratio and market return. Marcelo and Quiros (2006) studied illiquidity risk factor in Spanish Stock Market between 1994 and 2002. They added illiquidity risk factor to Fama and French three-factor model. Their findings show that illiquidity factor should be considered as a key element of asset pricing. The relationship between risk and stock return is repeatedly studied in Tehran Stock Exchange. The findings show that there is no significant relationship between stock illiquidity as a risk factor and stockholders' excess return in Tehran Stock Exchange (Salimpor, 2005). In 2007, Javad Khoramdin studied the role of illiquidity risk, firm size, book to market equity ratio and market excess return on stock excess return in Tehran Stock Exchange. It means that illiquidity and firm size have a negative relation to stock excess return while the relationship between market excess return and book to market equity with stock excess return is positive. Yahyazadeh et al. (2010) studied the relationship between liquidity and stock return in Tehran Stock Exchange. Their findings indicated a positive and significant relationship between varied ratio of turnover rate and stock return. It may be due to the increase in liquidated stock attractiveness and increase in demand for such hypes of stocks.

\section{Literature and Conceptual Framework}

For many years, liquidity was recognized as one of the most important ground of innovation. So far, paramount researches are conducted on affecting factors on asset returns. The findings of a research by Amihud indicate that stock expected returns have negative relationship to liquidity both periodically and overtime. He showed that a part of stock excess return is a compensation for market expected illiquidity. Researches by Maihud \& Mendelson, Bernan et al, Datar et al, Jacoby et al as well as Amihud and Ben Marshall indicate a negative relationship between liquidity and asset expected return. All above researches show that liquidity is an important affecting factor on investors' portfolio decisions. Therefore, logic investors need a higher risk premium to retain more illiquidity securities and they consider such rate of liquidity when they are forming their portfolio. However, relative less attention is paid to direct merging of liquidity into portfolio formation. Liu defines liquidity as: "asset liquidity is the capability of rapid transaction of a high volume of securities with low cost and 
low price effect." Low price effect means that the asset price is not changed between order and purchase. Liquidity is a multidimensional criterion. Since there is no unique criterion that can cover all aspects of liquidity, several separated criteria are inevitably used that each one explains a dimension of liquidity. So far, alternative variable are introduced for liquidity such transaction value, transaction quantity, transaction volume, stock transaction turnover and Bid - Ask Spread. Datar et al introduced two advantages to use stock transaction turnover as an alternative variable. The first one enjoys strong theoretical basics and in the second one, it is relatively easy to find stock transaction turnover data. It should be noted that due to the system of Tehran Stock Exchange, it is too difficult to obtain data to compute Bid - Ask Spread (Eslami Bidgoli and Saranj, 2008). Based on recent initiatives for an efficient capital market in national financial regime and increasing the knowledge of financial practitioners and analysts, it is expected that studied variables especially liquidity enjoy more power in determining stock return.

\section{Research Hypotheses}

(A) There is a significant relationship between portfolio excess return and market excess return $\left(\mathrm{R}_{\mathrm{m}}-\mathrm{R}_{\mathrm{f}}\right)$.

(B) There is a significant relationship between portfolio excess return and firm size (size premium).

(C) There is a significant relationship between portfolio excess return and book to market equity (value premium).

(D) There is a significant relationship between portfolio excess return and stock transaction turnover (liquidity premium).

\section{Research Variables}

In present study, monthly return of portfolio is considered as dependent variable and market excess return, firm size(ME), book to market equity(BE/ME) and stock transaction turnover are selected as independent variables. Fama and French three-factor model is used to define dependent and independent variables. Stock return is the total return of stock price changes and profits of ownership (dividend, bonus shares...) during one year. Market excess return is the difference between market return and risk-free return $\left(\mathrm{R}_{\mathrm{m}}-\mathrm{R}_{\mathrm{f}}\right)$. Market return is the average of return rate acquired through stock transactions in Tehran Stock Exchange. There are various indices such as total price, cash return and price to compute market return. Firm's size is computed by multiplying the number of stock at the end of firm's period in the average of stock price in the same year. The ratio of book to market equity (BE/ME) is achieved by dividing firm's common stock book value at the end of fiscal year on stock common market value. Since the end of fiscal year for registered firms in Tehran Stock Exchange is end of Iranian Esfand month (mid March), the value is computed by dividing book value on market value at the end of fiscal year. Stock transaction turnover defined as the ratio of transacted stocks during one period to the number of issued stocks at the end of the same period is used as liquidity measurement. Noteworthy, TEDPIX is used as the alternative variable for market portfolio and bond guaranteed interest rate is used as the alternative variable for risk-free return rate. The rates of bonds return in recent years are acquired by resorting to the economic reports and balance sheets issued by Iranian Central Bank (2004 - 2008). This rate was \%17 in 2004 and \%15.5 between 2005 through 2008).

\section{Research Statistical Population and Sample}

Research statistical population consists of all registered firms in Tehran Stock Exchange between 2004 and 2008. Its sample includes 68 firms selected by scanning method and following measures:

1. Firms with similar fiscal year.

2. Competent firms should not face negative book value (BE).

3. Firms whose transactional index is not closed more than 3 months.

4. This research is conducted for nonfinancial firms so investment firms, banks and holdings are excluded because that their value is a function of their portfolio changes and combination. Firms inside financial intermediary industry do not have similar portfolio in Stock Exchange. Therefore, industry factor does not impact on them.

5. The firms should not face losses during research period. In other words, they should not have negative EPS.

6. During research period, the firms should have at least 50 transactions per day.

To calculate stock monthly return and independent variables, Tadbir Pardaz databank was used. Noteworthy, EVIEWS, SPSS and Excel software are used to analyze statistical data. 


\section{Methodology}

Risk factor analysis (IML, HML and SMB) is used in present study. Black et al method is used for such analysis. Based on methodology, risk factors were recognized and then these factors were used as independent variable for regression analysis. This approach is used in various studies on capital asset pricing models successfully. Noteworthy, Fama and French (1993) approach was initially used to devise dependent variables in risk factor regression.

At the end of each year, all firms are classified by their sizes and then the middle firm is used to divide stocks into two groups. The first group includes stocks whose market value is less than mean and the second one includes stocks whose market value is greater than mean. Firms were classified as three ranks (low, middle, high) by Fama and French model as well as BE/ME ratio. In this line, $\% 30$ of the minimum ranks were belonged to low firms, $\% 40$ to middle ones and \%30 to high firms. According to Fama and French model and stock transaction turnover, firms were classified from high to low. In this regard, firms whose stock transaction turnover was greater than $\% 30$ were classified as high stock transaction turnover (L), $\% 40$ as middle (M) and $30 \%$ as low firms(I).

\subsection{Forming Portfolios on the Basis of SMB and HML Factors}

After classifying firms' shares based on two size and the ratio of book to market equity factors, stocks are classified into six portfolios as a combination of size and BE/ME.

$\mathrm{S} / \mathrm{L}_{(\mathrm{BE} / \mathrm{ME})}, \mathrm{S} / \mathrm{M}_{(\mathrm{BE} / \mathrm{ME})}$ and $\mathrm{S} / \mathrm{H}_{(\mathrm{BE} / \mathrm{ME})}$ : firms small in size with low, medium and high $\mathrm{BE} / \mathrm{ME}$ respectively.

$\mathrm{B} / \mathrm{L}_{(\mathrm{BE} / \mathrm{ME})}, \mathrm{B} / \mathrm{M}_{(\mathrm{BE} / \mathrm{ME})}$ and $\mathrm{B} / \mathrm{H}_{(\mathrm{BE} / \mathrm{ME})}$ : firms large in size with low, medium and high $\mathrm{BE} / \mathrm{ME}$ respectively.

\subsection{Forming Portfolios on the Basis of SMB and IML Factors}

After classifying firms' shares based on two size and stock transaction turnover factors, stocks are classified into six portfolios as a combination of size and stock transaction turnover.

$\mathrm{S} / \mathrm{I}_{\text {(turnover) }}, \mathrm{S} / \mathrm{M}_{\text {(turnover) }}$ and $\mathrm{S} / \mathrm{L}_{\text {(turnover) }}$ : firms small in size with low, medium and high transaction turnover respectively.

$\mathrm{B} / \mathrm{I}_{\text {(turnover) }}$, $\mathrm{B} / \mathrm{M}_{\text {(turnover) }}$ and $\mathrm{B} / \mathrm{L}_{\text {(turnover) }}$ : firms large in size with low, medium and high transaction turnover respectively.

SMB, HML and IML variables are portfolios with zero investment and their sensation to a risk potential factor is shown by the variable upon which they are shaped. More specifically, a base portfolio is formed by buying stocks with high risks and selling stocks with low risk.

\section{Research Model}

Portfolio average return is a dependent variable related to research model and market excess return, firm size (ME), the ratio of book to market equity and stock transaction turnover are considered as independent variables in below multiple regression model by using time interval regression method over data with monthly data.

$$
R_{i t}-R_{f t}=a_{i}+b_{i} \times M K T_{t}+s_{i} \times S M B_{t}+h_{i} \times H M L_{t}+t_{i} \times I M L_{t}+\varepsilon_{i t}
$$

Where:

$\mathrm{a}_{\mathrm{i}}$ : width from origin;

$\mathrm{t}_{\mathrm{i}}, \mathrm{h}_{\mathrm{i}}, \mathrm{s}_{\mathrm{i}}, \mathrm{b}_{\mathrm{i}}$ : regression ratios for i portfolio on factors;

$\mathrm{R}_{\mathrm{it}}$ : achieved average return from i portfolio in the $\mathrm{t}^{\text {th }}$ month computed as simple average

$\mathrm{MKT}_{\mathrm{t}}$ : market excess return obtained by the difference of market portfolio return in $\mathrm{t}$ period and risk-free return in $t$ period $\left(\mathrm{R}_{\mathrm{m}}-\mathrm{R}_{\mathrm{f}}\right)$.

$\mathrm{SMB}_{\mathrm{t}}$ : difference between the average return of two portfolios with market small and great value in $\mathrm{t}$ period;

$$
S M B=[(S / L+S / M+S / H) / 3]-[(B / L+B / M+B / H) / 3]
$$

This factor is a tool to show a part of return variance which relates to firm's size (Kimiagary et al., 2007). Therefore, SMB is the difference between average returns of two portfolios with small and large sizes where book value is as same as market value. In fact, SMB should be free of the impact of book value on market value. This is achieved by focusing on the behavioral difference of small and larger stocks.

$\mathrm{HML}_{\mathrm{t}}$ : the difference between the average return of two portfolios with high and low book value ratio to market value in $t$ period: 


$$
H M L=[(S / H+B / H) / 2]-[(S / L+B / L) / 2]
$$

This factor is a tool to achieve risk factor of book value ratio to market value. In facts, HML is the difference between average returns of two portfolios with book value ratio to high market value $(\mathrm{B} / \mathrm{H}$ and $\mathrm{S} / \mathrm{H})$ and book value ratio to low market value $(\mathrm{B} / \mathrm{L}$ and $\mathrm{S} / \mathrm{L})$. Two components of HML namely high and low $\mathrm{BE} / \mathrm{ME}$ are similar. Therefore, HML is fully free of size effect on returns by focusing on the behaviors of stocks with high and low BE/ME.

$\mathrm{IML}_{\mathrm{t}}$ : it is the difference between average return of two portfolios with low and high stock transaction turnover in t period; it is generally called liquidity premium and calculated as:

$$
I M L=[(S / I+B / I) / 2]-[(S / L+B / L) / 2]
$$

This factor is a tool to achieve risk factor of liquidity variable. In fact, IML is the difference between the returns of two portfolios with low stock transaction return (B/I and $\mathrm{S} / \mathrm{I})$ and high stock transaction return $(\mathrm{B} / \mathrm{L}$ and $\mathrm{S} / \mathrm{l})$. Two components of IML namely high and low BE/ME are similar. Therefore, IML is fully free of size effect on returns by focusing on the behaviors of stocks with high and low BE/ME. Note that like HML, S/M and B/M portfolio are not considered in forming IML factor.

$\varepsilon_{\mathrm{it}}$ : it is the random error or liquidation of $\mathrm{i}$ portfolio in $\mathrm{t}^{\text {th }}$ month.

\subsection{Regression Classic Hypotheses}

Regressive methods are based on hypotheses. To perform regressive analyses, their classic hypotheses should be considered. If such hypotheses do not exist, the credit of regressive models would be under question. The main hypotheses include:

(1) The lack of perfect multicollinearity between independent variables means that there is no precise linear relationship between independent variables (table 1. Monthly correlation coefficients matrix between variables).

(2) There is linear relationship between independent and dependent variables.

(3) The lack of autocorrelation between independent variable namely $E(\varepsilon i, \varepsilon j)=o(i \neq j)($ Table 2. The results of Durbin - Watson test on the lack of autocorrelation).

(4) Homoskedasticity namely $\mathrm{E}\left(\varepsilon_{\mathrm{t}}^{2}\right)=\sigma^{2},(\mathrm{t}=1,2,3, \ldots, \mathrm{n})$ (Table 3. The results of White's test to examine homoskedasticity).

\subsection{Correlation Coefficient Matrix between Independent Variables}

Before regression analysis, one should initially examine the correlation between independent variables. By obtaining coefficient correlations between such figures, IML, HML and SMB variables should be controlled monthly to see whether there is high correlation between them or not. By recognizing low correlation between these three variables, the main part of regression analysis is done. As table 1 displays, the highest correlation -0.433 existed between HML and SMB.

\section{Four-factor Model Analysis}

In this section, the final step is taken to test four-factor model in the sample. Before analyzing the results, it is better to provide descriptions on selecting 12 portfolios as dependent variables.

The main reason of using these portfolios is that by forming portfolios on such basis, each portfolio includes stocks that have different and clear risks and returns. Otherwise, one cannot judge on the argument power of size variable and the ratio of book to market equity if the portfolio is selected randomly with various characteristics (Kimiagari et al, 2007). Below, four-factor model is investigated based in the research model for 12 portfolios. The results of four-factor model fitness are shown in tables. (Tables 4 and 5. The results of Four-Factor Regression).

According to tables 4 and 5, F significant test in all 12 portfolios is less than 0.05 . As a result, $\mathrm{H}_{0}$ is refused and $\mathrm{H}_{1}$ on the statistical significance relationship between all independent variables (4 variables) is accepted by 0.95 confidence return. Also, $\mathrm{R}^{2}$ ratios are different in these portfolios between $\% 20$ and $\% 64$ which show four factors including market excess return, firm's size, the ratio of book to market equity and stock transaction turnover in a four factor model in all 12 portfolios clarify return premium changes $\left(\mathrm{R}_{\mathrm{i}}-\mathrm{R}_{\mathrm{f}}\right)$ as an average of $\% 40$ where the portfolios of the firms with high liquidity $\left(\mathrm{B} / \mathrm{L}_{(\text {turnover) }}\right.$ and $\left.\mathrm{S} / \mathrm{L}_{(\text {turnover })}\right)(\% 63$ as average) and in the portfolios of small firms with high book to market equity $\left(\mathrm{S} / \mathrm{H}_{(\mathrm{BE} / \mathrm{ME})}\right)(\% 55$ as average) with the highest return clarification power. 


\section{Conclusion}

Multivariable method is used to test research hypotheses. F tests are used to investigate the significance of total model and $t$ test is used to the significance of regression ratios.

In present study, the relationship between market excess return, firm's size, the ratio of book to market equity and liquidity on stock return in Tehran Stock Exchange was studied by using Fama and French three-factor model. In present study, time series analyses were used between 2004 and 2008. Market excess return, firm's size (SMB), the ratio of book to market equity (HML) and liquidity (IML) are used as independent variables and portfolios excess return is used as dependent variable. The results are as follow:

\subsection{By Considering Hypothesis (A)}

There is a significant relationship between portfolio excess return and market excess return $\left(\mathrm{R}_{\mathrm{m}}-\mathrm{R}_{\mathrm{f}}\right)$.

By considering the results in 0.05 significance level ( 0.95 confidence level), there is a direct and significance relationship between market risk and stock return of registered firms in Tehran Stock Exchange which is compatible with the results of Bans' results (1981) and Fama and French (1992) and with Bagherzadeh (2005), Taremi (2006) and Kimiagari (2007) in Iran.

\subsection{By Considering Hypothesis (B)}

There is a significant relationship between portfolio excess return and firm's size (size premium).

By considering the results in 0.05 significance level ( 0.95 confidence level), there is a significance relationship between firm's size and stock return of registered firms in Tehran Stock Exchange which the relationship between the return of small firms (S) and firm's size is positive and the relationship between big firms (B) and firm's size is negative. These results are compatible with the results of Bans' results (1981) and Fama and French (1992) and with Bagherzadeh (2005) and Kimiagari (2007) in Iran.

\subsection{By Considering Hypothesis (C)}

There is a significant relationship between portfolio excess return and book to market equity (value premium).

By considering the results in 0.05 and 0.10 significance levels ( 0.95 and 0.90 confidence levels) and the equal number of confirmed/unconfirmed portfolios, one can conclude that $\mathrm{H}_{0}$ is supported and $\mathrm{H} 1$ on the existence on a significant statistical relationship between the ratios of book to market equity is not supported. By studying the portfolios individually, one can conclude the significant and positive relationship of HML variable and the return of firms with high ratio of book value to market value. Research findings show that this variable plays a weaker role in Iranian capital market to clarify return. These findings are in contrary to findings by Fama and French (1992) and Chan, Hama and Lockney Shock (1991). They are compatible to research conducted by (2005) and Kimiagari et al (2007) in Iran.

\subsection{By Considering Hypothesis (D)}

There is a significant relationship between portfolio excess return and stock transaction turnover (liquidity premium).

By considering the results in 0.05 and 0.10 significance levels ( 0.95 and 0.90 confidence levels) the relationship between stock transaction turnover and the return of small firms with low liquidity is significant and positive and it is significant and negative for small and big firms with high liquidity. Overall, there is no significant relationship between stock transaction turnover and the return of registered firms in Tehran Stock Exchange. It is in contrary to findings by Datar et al (1999) and Wisely et al 2002). On the other hand, it is compatible to Rouen Hust (1999) in emerging markets and Ghaemi (2000) and Salimpour (2005) in Iran.

\section{References}

Amihud, Yakov, \& Mendelson, Haim. (1986). Asset pricing and the bid-ask spread. Journal of Financial Economics, 17, 223-249. http://dx.doi.org/10.1016/0304-405X(86)90065-6

Bagherzadeh, Saeed. (2005). affecting factors on stock return in Tehran Stock Exchange. Financial Research Quarterly, 19, Tehran University Management School Publications.

Constantinides, G.M., Harris, M., \& Stalz, R. (2003). Handbook of the Economics of Finance, Edited by Elsevier B.V., 1036-1041.

Chui, A., \& Wei, J. (1998). Book-to-market, firm size, and the turn-of-the-year effect: Evidence from Pacific-Basin emerging markets. Pacific-Basin finance journal, 6, 275-293. http://dx.doi.org/10.1016/S0927-538X(98)00013-4. 
Datar, Vinay T., Naik, Narayan Y., \& Radcliffe, Robert. (1998). Liquidity and stocks return: An alternative test. journal of Financial Markets, 1, 203-219. http://dx.doi.org/10.1016/S1386-4181(97)00004-9

Easley, David, Hvidkjaer, S., \& O'Hara, Maureen. (2002). Is Information Risk a Determinant of Asset Return?. Journal of Finance, 57, 2185-2221. http://dx.doi.org/ 10.1111/1540-6261.00493

Fama, Eugene F., \& French, Kenneth R. (1992). The cross-Section of Expected Stock Returns. Journal of Finance, 47, 427-465. http://dx.doi.org/ 10.1111/j.1540-6261.1992.tb04398.x

Fama, Eugene F., \& French, Kenneth R. (1993). Common risk factor in the returns on stocks and bonds. Journal of Financial Economics, 33, 3-56. http://dx.doi.org/10.1016/0304-405X(93)90023-5

Ghaemi, Mohammad Hussein. (2000). Studying the affecting factors on expected return of registered firms in Tehran Stock Exchange. Accounting doctoral thesis, University of Tehran.

Islami Bidgoli, Gholam Reza, \& Sarenj, Ali Reza. (2008). selecting portfolio by using three measures of return average, return measure deviation and liquidity in Tehran Stock Exchange. Accounting and Auditing Quarterly, 53, Tehran University Management School Publications.

Khoramdin, Javad. (2007). The role of illiquidity risk, size, BV/MV and market excess return on stock excess return in Tehran Stock Exchange. M.A. thesis, Mazandaran University.

Kimiagari, Mohammad Ali., Islami Bidgol, Gholam Reza, \& Eskandari, mehdi. (2007). Studying the relationship between risk and return in Tehran Stock Exchange based on Fama and French three-factor model. Financial Research Quarterly, 23, Tehran University Management School Publications.

Lee, Charles M.C., \& Swaminathan, Bhaskaran. (2000). Price momentum and trading volume. Journal of Finance, 55, 2017-2069. . http://dx.doi.org/10.1111/0022-1082.00280

Liu, Weimin. (2006). A liquidity-augmented capital asset pricing model. Journal of Financial Economics, 82, 631-671. http://dx.doi.org/10.1016/j.jfineco.2005.10.001

Marcelo, Miralles, \& Quiros, Miralles. (2006). The role of an illiquidity risk factor in asset pricing: empirical evidence from the Spanish stock market. The Quaterly Review of Economics and Finance, 46, 254-267. http://dx.doi.org/10.1016/j.qref.2005.08.002

Salimpour, Maryam. (2005). Studying the impact of stock liquidty on stock excess return of registered firms in Tehran Stock Exchange. M.A. Thesis, Shahid Beheshti University.

Robatmeili, Mojgan. (2007). Comparing the performance of CAPM and three-factor model of Fama and French in forecasting the expected return in Tehran Stock Exchange. M.A. thesis, Alzahra University.

Rouwenhorst, K. Greet. (1999). Local return factors and turnover in emerging stock markets. Journal of Finance, 54, 1439-1464. http://dx.doi.org/ 10.1111/0022-1082.00151

Sharp, William F. (1964). Capital asset prices: a theory of market equilibrium under conditions of risk. Journal of Finance, 19, 425-442. http://dx.doi.org/ 10.2307/2977928

Tang, G. Y. N., \& Shum, W. C. (2005). Common risk factors in returns in Asian emerging stock markets. International Business Review, 14, 695-717. http://dx.doi.org/10.1016/j.ibusrev.2005.09.001

Tehrani, Reza, \& Sadeghi Sharif, Seyed Jalal. (2004). clarifying capital asset pricing model in Tehran Stock Exchange. Financial Research Quarterly, 18, Tehran University Management School Publications. 


\section{Appendix}

Table 1. Monthly correlation coefficients matrix between variables

\begin{tabular}{cccccc}
\hline & & MKT & SMB & HML & IML \\
\hline MKT & Pearson Correlation & 1 & .030 & -.216 & -.027 \\
& Sig. (2-tailed) & & .821 & .097 & .841 \\
& $\mathrm{~N}$ & 60 & 60 & 60 & 60 \\
\hline \multirow{2}{*}{ SMB } & Pearson Correlation & .030 & 1 & $-.433(* *)$ & -.010 \\
& Sig. (2-tailed) & .821 & & .001 & .940 \\
& $\mathrm{~N}$ & 60 & 60 & 60 & 60 \\
\hline \multirow{2}{*}{ HML } & Pearson Correlation & -.216 & $-.433(* *)$ & 1 & -.138 \\
& Sig. (2-tailed) & .097 & .001 & & .292 \\
& $\mathrm{~N}$ & 60 & 60 & 60 & 60 \\
\hline \multirow{2}{*}{ IML } & Pearson Correlation & -.027 & -.010 & -.138 & 1 \\
& Sig. (2-tailed) & .841 & .940 & .292 & \\
& $\mathrm{~N}$ & 60 & 60 & 60 & 60 \\
\hline
\end{tabular}

** Correlation is significant at the 0.01 level (2-tailed).

Table 2. The results of Durbin - Watson test on the lack of autocorrelation

\begin{tabular}{cccc}
\hline Portfolio & $\begin{array}{c}\text { Durbin-Watson } \\
\text { Accepted interval } \\
(1.67 \ldots 2.33)\end{array}$ & Result & $\begin{array}{c}\text { Elimination of } \\
\text { Autocorrelation }\end{array}$ \\
\hline $\mathrm{S} / \mathrm{L}_{\text {(BE/ME) }}$ & 1.722 & No autocorrelation & - \\
$\mathrm{S} / \mathrm{M}_{(\mathrm{BE} / \mathrm{ME})}$ & 1.492 & Autocorrelation & $\mathrm{AR}(1)$ \\
$\mathrm{S} / \mathrm{H}_{(\mathrm{BE} / \mathrm{ME})}$ & 1.783 & No autocorrelation & - \\
$\mathrm{B} / \mathrm{L}_{\text {(BE/ME) }}$ & 1.987 & No autocorrelation & - \\
$\mathrm{B} / \mathrm{M}_{\text {(BE/ME) }}$ & 1.773 & No autocorrelation & - \\
$\mathrm{B} / \mathrm{H}_{(\mathrm{BE} / \mathrm{ME})}$ & 1.745 & No autocorrelation & - \\
$\mathrm{S} / \mathrm{I}_{\text {(turnover) }}$ & 1.241 & Autocorrelation & $\mathrm{AR}(1)$ \\
$\mathrm{S} / \mathrm{M}_{\text {(turnover) }}$ & 1.986 & No autocorrelation & - \\
$\mathrm{S} / \mathrm{L}_{\text {(turnover) }}$ & 1.598 & No autocorrelation & $\mathrm{AR}(1)$ \\
$\mathrm{B} / \mathrm{I}_{\text {(turnover) }}$ & 1.915 & No autocorrelation & - \\
$\mathrm{B} / \mathrm{M}_{\text {(turnover) }}$ & 1.483 & Autocorrelation & $\mathrm{AR}(1)$ \\
$\mathrm{B} / \mathrm{L}_{\text {(turnover) }}$ & 1.488 & Autocorrelation & $\mathrm{AR}(1)$ \\
\hline
\end{tabular}


Table 3. The results of White's test to examine homoskedasticity

\begin{tabular}{ccccc}
\hline Portfolio & $\begin{array}{c}\text { Calculated } \\
\text { statistic }\end{array}$ & Error level & Result & $\begin{array}{c}\text { The method to remove no } \\
\text { homoskedasticity }\end{array}$ \\
\hline $\mathrm{S} / \mathrm{L}_{\text {(BE/ME) }}$ & 11.88066 & 0.0000 & No Homoskedasticity & Using dispersion heterogeneity \\
$\mathrm{S} / \mathrm{M}_{\text {(BE/ME) }}$ & 3.179470 & 0.0011 & No Homoskedasticity & Using dispersion heterogeneity \\
$\mathrm{S} / \mathrm{H}_{\text {(BE/ME) }}$ & 6.571896 & 0.0000 & No Homoskedasticity & Using dispersion heterogeneity \\
$\mathrm{B} / \mathrm{L}_{\text {(BE/ME) }}$ & 8.627225 & 0.0000 & No Homoskedasticity & Using dispersion heterogeneity \\
$\mathrm{B} / \mathrm{M}_{\text {(BE/ME) }}$ & 1.108788 & 0.3765 & Homoskedasticity & \\
$\mathrm{B} / \mathrm{H}_{\text {(BE/ME) }}$ & 9.989877 & 0.0000 & No Homoskedasticity & Using dispersion heterogeneity \\
$\mathrm{S} / \mathrm{I}_{\text {(turnover) }}$ & 2.201994 & 0.0178 & No Homoskedasticity & Using dispersion heterogeneity \\
$\mathrm{S} / \mathrm{M}_{\text {(turnover) }}$ & 4.186489 & 0.0001 & No Homoskedasticity & Using dispersion heterogeneity \\
$\mathrm{S} / \mathrm{L}_{\text {(turnover) }}$ & 2.943639 & 0.0020 & No Homoskedasticity & Using dispersion heterogeneity \\
$\mathrm{B} / \mathrm{I}_{\text {(turnover) }}$ & 3.493698 & 0.0007 & No Homoskedasticity & Using dispersion heterogeneity \\
$\mathrm{B} / \mathrm{M}_{\text {(turnover) }}$ & 3.474904 & 0.0007 & No Homoskedasticity & Using dispersion heterogeneity \\
$\mathrm{B} / \mathrm{L}_{\text {(turnover) }}$ & 2.460593 & 0.0113 & No Homoskedasticity & Using dispersion heterogeneity \\
\hline
\end{tabular}


Table 4. The results of Four-Factor Regression

\begin{tabular}{|c|c|c|c|c|c|c|c|}
\hline \multicolumn{8}{|c|}{ The Four Factor Model } \\
\hline \multicolumn{8}{|c|}{$\mathrm{R}_{\mathrm{it}}-\mathrm{R}_{\mathrm{ft}}=\mathrm{a}_{\mathrm{i}}+\mathrm{b}_{\mathrm{i}} \times \mathrm{MKT}_{\mathrm{t}}+\mathrm{s}_{\mathrm{i}} \times \mathrm{SMB}_{\mathrm{t}}+\mathrm{h}_{\mathrm{i}} \times \mathrm{HML}_{\mathrm{t}}+\mathrm{t}_{\mathrm{i}} \times \mathrm{IML}_{\mathrm{t}}+\varepsilon_{\mathrm{it}}$} \\
\hline Portfolios & Variables & Ratios & t-statistic & P-value & F-statistics & P-value & R-squared \\
\hline \multirow{5}{*}{$\mathrm{S} / \mathrm{L}_{(\mathrm{BE} / \mathrm{ME})}$} & MKT & 0.347297 & 1.741464 & 0.0872 & \multirow{5}{*}{12.59099} & \multirow{5}{*}{0.0000} & \multirow{5}{*}{0.4780} \\
\hline & SMB & 0.713545 & 3.416588 & 0.0012 & & & \\
\hline & HML & -0.426177 & -2.439378 & 0.018 & & & \\
\hline & IML & -0.11758 & -0.398323 & 0.6919 & & & \\
\hline & Constant & 0.250637 & 0.253682 & 0.8007 & & & \\
\hline \multirow{5}{*}{$\mathrm{S} / \mathrm{M}_{(\mathrm{BE} / \mathrm{ME})}$} & MKT & 0.522436 & 3.277698 & 0.0019 & \multirow{5}{*}{7.512323} & \multirow{5}{*}{0.00002} & \multirow{5}{*}{0.414763} \\
\hline & SMB & 0.517472 & 3.039064 & 0.0037 & & & \\
\hline & HML & 0.258223 & 2.632344 & 0.0111 & & & \\
\hline & IML & -0.078706 & -0.588882 & 0.5584 & & & \\
\hline & Constant & 0.520478 & 0.611527 & 0.5435 & & & \\
\hline \multirow{5}{*}{$\mathrm{S} / \mathrm{H}_{(\mathrm{BE} / \mathrm{ME})}$} & MKT & 0.205428 & 1.699067 & 0.095 & \multirow{5}{*}{16.9175} & \multirow{5}{*}{0.00000} & \multirow{5}{*}{0.551643} \\
\hline & SMB & 0.796599 & 3.851535 & 0.0003 & & & \\
\hline & HML & 0.591241 & 3.162892 & 0.0025 & & & \\
\hline & IML & -0.172652 & -1.695572 & 0.0956 & & & \\
\hline & Constant & -0.602444 & -1.111444 & 0.2712 & & & \\
\hline \multirow{5}{*}{$\mathrm{B} / \mathrm{L}_{(\mathrm{BE} / \mathrm{ME})}$} & MKT & 0.32554 & 3.563844 & 0.0008 & \multirow{5}{*}{5.269978} & \multirow{5}{*}{0.0011} & \multirow{5}{*}{0.277076} \\
\hline & SMB & -0.191705 & -1.112542 & 0.2707 & & & \\
\hline & HML & 0.036421 & 0.383748 & 0.7026 & & & \\
\hline & IML & -0.005084 & -0.043329 & 0.9656 & & & \\
\hline & Constant & -1.031479 & -1.846208 & 0.0702 & & & \\
\hline \multirow{5}{*}{$\mathrm{B} / \mathrm{M}_{(\mathrm{BE} / \mathrm{ME})}$} & MKT & 0.467131 & 4.067723 & 0.0002 & \multirow{5}{*}{8.507433} & \multirow{5}{*}{0.00002} & \multirow{5}{*}{0.382229} \\
\hline & SMB & -0.363543 & -2.764493 & 0.0077 & & & \\
\hline & HML & -0.01793 & -0.183844 & 0.8548 & & & \\
\hline & IML & -0.30546 & -2.718534 & 0.0088 & & & \\
\hline & Constant & 0.610435 & 1.054022 & 0.2965 & & & \\
\hline \multirow{5}{*}{$\mathrm{B} / \mathrm{H}_{(\mathrm{BE} / \mathrm{ME})}$} & MKT & 0.169304 & 1.043873 & 0.3011 & \multirow{5}{*}{5.978669} & \multirow{5}{*}{0.00045} & \multirow{5}{*}{0.303045} \\
\hline & SMB & -0.269695 & -1.691773 & 0.0963 & & & \\
\hline & HML & 0.341303 & 3.018688 & 0.0038 & & & \\
\hline & IML & -0.016596 & -0.081415 & 0.9354 & & & \\
\hline & Constant & 1.528933 & 1.970158 & 0.0539 & & & \\
\hline
\end{tabular}


Table 5. The results of Four-Factor Regression

\begin{tabular}{|c|c|c|c|c|c|c|c|}
\hline \multicolumn{8}{|c|}{ The Four Facteor Model } \\
\hline \multicolumn{8}{|c|}{$\mathrm{R}_{\mathrm{it}}-\mathrm{R}_{\mathrm{ft}}=\mathrm{a}_{\mathrm{i}}+\mathrm{b}_{\mathrm{i}} \times \mathrm{MKT}_{\mathrm{t}}+\mathrm{s}_{\mathrm{i}} \times \mathrm{SMB}_{\mathrm{t}}+\mathrm{h}_{\mathrm{i}} \times \mathrm{HML}_{\mathrm{t}}+\mathrm{t}_{\mathrm{i}} \times \mathrm{IML}_{\mathrm{t}}+\varepsilon_{\mathrm{it}}$} \\
\hline Portfolios & Variables & Ratios & t-statistic & P-value & F-statistics & P-value & R-squared \\
\hline \multirow{5}{*}{$\mathrm{S} / \mathrm{I}_{\text {(turnover) }}$} & MKT & 0.307499 & 2.389224 & 0.0205 & \multirow{5}{*}{9.376849} & \multirow{5}{*}{0.000002} & \multirow{5}{*}{0.469386} \\
\hline & SMB & 0.335944 & 2.919955 & 0.0051 & & & \\
\hline & HML & 0.154224 & 1.993482 & 0.0514 & & & \\
\hline & IML & 0.35126 & 3.157531 & 0.0026 & & & \\
\hline & Constant & 1.811321 & 2.224618 & 0.0304 & & & \\
\hline \multirow{5}{*}{$\mathrm{S} / \mathrm{M}_{\text {(turnover) }}$} & MKT & 0.251518 & 2.263669 & 0.0277 & \multirow{5}{*}{4.024366} & \multirow{5}{*}{0.003609} & \multirow{5}{*}{0.275182} \\
\hline & SMB & 0.382633 & 1.983445 & 0.0525 & & & \\
\hline & HML & 0.219525 & 1.54838 & 0.1275 & & & \\
\hline & IML & -0.054835 & -0.417369 & 0.6781 & & & \\
\hline & Constant & 1.07346 & 1.778744 & 0.081 & & & \\
\hline \multirow{5}{*}{$\mathrm{S} / \mathrm{L}_{\text {(turnover) }}$} & MKT & 0.216367 & 2.070018 & 0.0433 & \multirow{5}{*}{19.57479} & \multirow{5}{*}{0.0000} & \multirow{5}{*}{0.648713} \\
\hline & SMB & 0.622445 & 5.38634 & 0.0000 & & & \\
\hline & HML & 0.262315 & 3.588362 & 0.0007 & & & \\
\hline & IML & -0.369802 & -4.093562 & 0.0001 & & & \\
\hline & Constant & 0.491671 & 0.917096 & 0.3632 & & & \\
\hline \multirow{5}{*}{$\mathrm{B} / \mathrm{I}_{\text {(turnover) }}$} & MKT & 0.258423 & 3.21103 & 0.0022 & \multirow{5}{*}{4.84209} & \multirow{5}{*}{0.002035} & \multirow{5}{*}{0.260438} \\
\hline & SMB & -0.234706 & -1.644809 & 0.1057 & & & \\
\hline & HML & 0.03382 & 0.400955 & 0.6900 & & & \\
\hline & IML & 0.075619 & 0.691896 & 0.4919 & & & \\
\hline & Constant & 0.754702 & 1.630275 & 0.1088 & & & \\
\hline \multirow{5}{*}{$\mathrm{B} / \mathrm{M}_{\text {(turnover) }}$} & MKT & 0.262401 & 2.459288 & 0.0172 & \multirow{5}{*}{2.657257} & \multirow{5}{*}{0.032386} & \multirow{5}{*}{0.200438} \\
\hline & SMB & -0.135917 & -0.903258 & 0.3705 & & & \\
\hline & HML & 0.035818 & 0.460913 & 0.6467 & & & \\
\hline & IML & -0.003576 & -0.044752 & 0.9645 & & & \\
\hline & Constant & 0.816013 & 1.102832 & 0.2751 & & & \\
\hline \multirow{5}{*}{$\mathrm{B} / \mathrm{L}_{\text {(turnover) }}$} & MKT & 0.559717 & 3.873402 & 0.0003 & \multirow{5}{*}{15.04081} & \multirow{5}{*}{0.0000} & \multirow{5}{*}{0.586597} \\
\hline & SMB & -0.36518 & -2.531355 & 0.0144 & & & \\
\hline & HML & 0.017887 & 0.210873 & 0.8338 & & & \\
\hline & IML & -0.498293 & -3.694383 & 0.0005 & & & \\
\hline & Constant & 1.303668 & 1.848969 & 0.07 & & & \\
\hline
\end{tabular}

